\title{
Arylfurans as potential Trypanosoma cruzi trypanothione reductase inhibitors
}

\author{
Renata B de O liveira, Aline BM Vaz, Rosana 0 Alves*, Daniel B Liarte*, \\ Claudio L Donnici**, Alvaro J Romanha*, Carlos L Zani/ ${ }^{+}$
}

\begin{abstract}
Laboratório de Química de Produtos Naturais *Laboratório de Parasitologia Celular e Molecular, Centro de Pesquisas René Rachou-Fiocruz, Av. Augusto de Lima 1715, 30190-002 Belo Horizonte, MG, Brasil **NEQUIM - Departamento de Química, Instituto de Ciências Exatas, Universidade Federal de Minas Gerais, Belo Horizonte, MG, Brasil
\end{abstract}

The natural lignans veraguensin and grandisin have been reported to be active against Trypanosoma cruzi bloodstream forms. Aiming at the total synthesis of these and related compounds, we prepared three 2-arylfurans and eight 2,5-diarylfurans. They were evaluated for their potential as T. cruzi trypanothione reductase (TR) inhibitors as well against the parasite's intracellular (amastigote) and bloodstream (trypomastigote) forms. Compound 12 was the most effective against $T R$ with an $I C_{50}$ of $48.5 \mu M$ while 7 and $\mathbf{1 4}$ were active against amastigotes, inhibiting the parasite development by $60 \%$ at $20 \mu \mathrm{g} / \mathrm{ml}$ (59 and $90 \mu \mathrm{M}$, respectively). On the other hand, none of the compounds was significantly active against the parasite bloodstream forms even at 250 $\mu \mathrm{g} / \mathrm{ml}(0.6-1.5 \mathrm{mM})$.

Key words: tropical diseases - Chagas disease - arylfurans - trypanothione reductase

Chagas disease, caused by the flagellate protozoan Trypanosoma cruzi, affects 18 million people in Latin America and is responsible for 13,000 deaths every year (WHO 2002). The treatment relies on only two available drugs, nifurtimox and benznidazole, which are relatively efficient in the acute phase of the disease, but almost ineffective in the chronic phase. Nowadays, one of the most important mechanisms of Chagas disease transmission in many countries is by blood transfusion (Schmuñis 1991). In highly endemic areas it is strongly recommended the use of chemoprophylatic measures such as the addition of gentian violet to clear trypomastigotes from blood banked for transfusion (Moraes-Souza et al. 1995). Although effective, this triphenylmethane dye is not well accepted because of undesirable effects such as coloring the skin and possible mutagenicity (Wendel 1993). Thus, new drugs to treat or prevent Chagas disease are still needed.

Trypanosoma cruzi enzymes such as the trypanothione reductase (TR) represent a potential drug targets because they play an essential role in the life of this parasite. TR and its substrate trypanothione, the disulfide of a glutathione-spermidine conjugate $\left[N^{1}, N^{8}\right.$ bis(glutathionyl)spermidine, $\left.\mathrm{T}(\mathrm{SH})_{2}\right] \mathbf{1}$, help to protect the parasite from oxidative stress by maintaining an intracellular reducing environment in a manner analogous to glutathione reductase (GR) and glutathione [L- $\gamma$-glutamyl-Lcysteiylglycine, GSH] 2 (Fig. 1a) in mammalian cells (Schmidt \& Krauth-Siegel 2002). TR catalyses the NADPHdependent reduction of trypanothione disulfide $\mathrm{TS}_{2}$ to its

Financial support: Fiocruz, CNPq, Fapemig +Corresponding author: zani@cpqrr.fiocruz.br Received 4 November 2005

Accepted 8 March 2006 dithiol form, $\mathrm{T}(\mathrm{SH})_{2}$. Trypanothione may be oxidized back to $\mathrm{TS}_{2}$ (Fig. 1b) following reaction with potentially damaging radicals and oxidants generated by aerobic metabolism. Another aspect that makes TR an even more attractive target is its structural differences from the human counterpart GR. GR has a narrow positively charged active site, to accommodate the glycine carboxylates of its substrate glutathione, whereas TR has a wider, noncharged, and more hydrophobic active site (Bond et al. 1999). These differences allowed the discovery of several promising selective inhibitors of TR (Schmidt \& KrauthSiegel 2002)

Lignans is a class of natural products that possess important biological properties (Jensen et al. 1993). Lopes et al. (1998) showed that the tetrahydrofuran lignans veraguensin 3 and grandisin 4 (Fig. 2) were active in vitro at $5 \mu \mathrm{g} / \mathrm{ml}$ against the trypomastigote of $T$. cruzi present in murine blood, causing $100 \%$ of parasite lysis without damaging erythrocytes. The activity of these lignans was

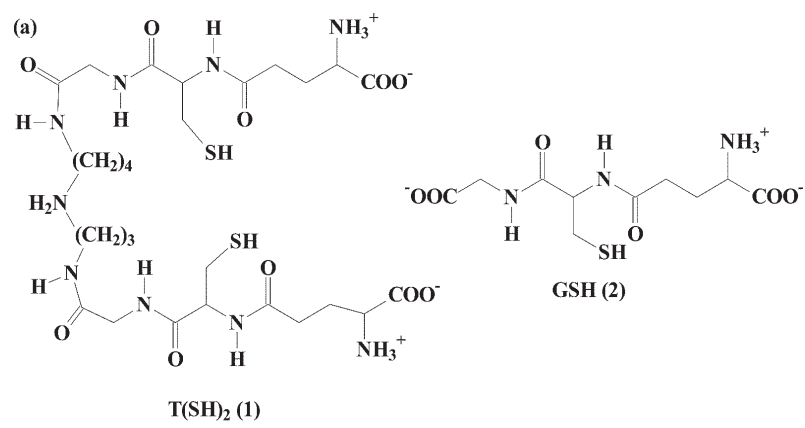

(b)

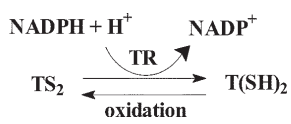

Fig.1: (a) chemical structure for trypanosomal trypanothione 1 and human glutathione 2; (b) trypanothione reductase (TR)catalysed reduction of $\mathrm{TS}_{2}$. 


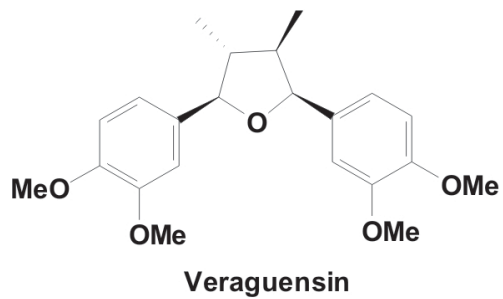

(3)

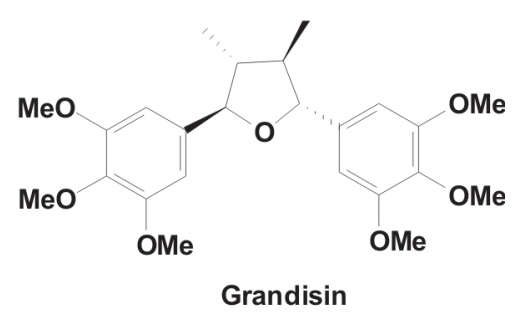

(4)

Fig. 2: lignans with trypanocydal activity isolated from Virola surinamensis (Lopes et al. 1998).

fifty times higher than that of the reference drug gentian violet.

Based on these promising results, we decided to synthesize these natural products and some analogues to evaluate their activity against $T$. cruzi. Our synthetic route to 3 and 4 (Fig. 3) involved arylfurans as intermediates.

Arylfurans present a broad-spectrum of biological activities [for example, antimicrobial activity (Stephens et al. 2001, Lanteri et al. 2004), effects against neurodegenerative, cardiovascular, and proliferative diseases (Lockhart et al. 2004), inhibitory activity against the enzymes farnesyltransferase (Mitsch et al. 2004) and PDE4 (Perrier et al. 1999), vascularization inhibitor effect (Kuwano et al. 1994)] and previous works (JockersScherübl et al. 1989, Paulino et al. 2002, Aguirre et al. 2004) have shown that furan derivatives could be potential ligands for TR. In view of these results, and aiming at the discovery of new trypanocidal compounds we evaluated the effect of the synthetic compounds 5-15 (Fig. 4) on TR and the whole trypomastigote and amastigote forms of the parasite.

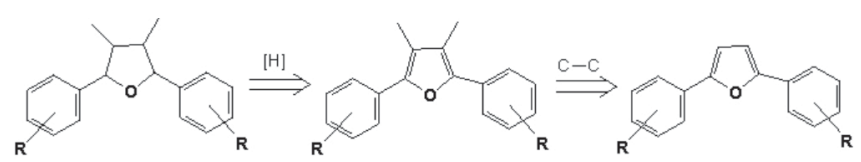

Fig. 3: arylfuran analogues of lignans 3 and $\mathbf{4}$
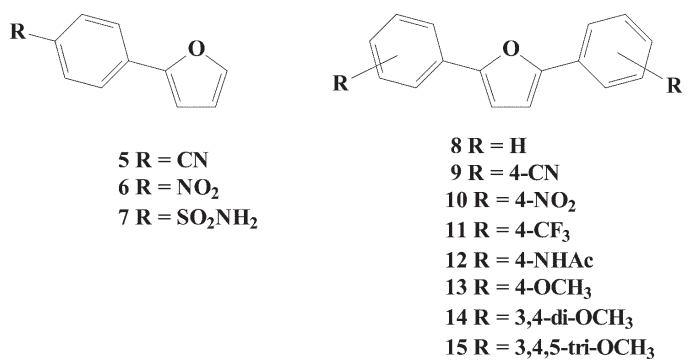

Fig. 4: chemical structures of 2-arylfurans (5-7) and 2,5-diarylfurans (8-15)

\section{MATERIALS AND METHODS}

Chemistry - The 2-arylfurans 5-7 and the 2,5-Bis( $p$ cyanophenyl)furan 9 were synthesized in one step using the classical Meerwein arylation (treatment of furan with diazonium salts in the presence of cupric salts) (Rondestvedt 1976). The 2,5-diarylfurans 8, 10-15 were prepared in two steps: (1) preparation of 2,5-bis (trimethylstannyl)furan $\mathbf{1 6}$ by reaction of furan with TMEDA and $n$-butyllithium and subsequent addition of trimethyltin chloride (Seitz et al. 1983), and (2) palladium catalyzed coupling reaction between the distannane $\mathbf{1 6}$ and various arylhalides (Stille coupling) (Stephens et al. 2001).

In vitro assay with $\mathrm{T}$. cruzi $T R$ - Recombinant $T$. cruzi TR was obtained as described by Borges et al. (1995). The colorimetric microtitre plate assay was adapted from that described by Hamilton et al. (2003). It was run in $40 \mathrm{mM}$ HEPES (pH 7.5), 1 mM EDTA, 0.12 mM NADPH and 0.8 $\mu \mathrm{M}$ trypanothione $\mathrm{TS}_{2}$ in a total assay volume of $250 \mu \mathrm{l}$. The test compounds were dissolved in DMSO and diluted with water to a final concentration of $0.1 \%(\mathrm{v} / \mathrm{v})$ DMSO. After addition of the enzyme $(5.12 \mathrm{mU} /$ well $)$ to the compound solution $(20 \mu \mathrm{g} / \mathrm{ml}, 50-120 \mu \mathrm{M})$ the mixture was incubated for $30 \mathrm{~min}$ at $30^{\circ} \mathrm{C}$, after which $25 \mu \mathrm{M}$ of 5,5'dithiobis-(2-nitrobenzoic acid) (DTNB) was added and the absorbance at $410 \mathrm{~nm}$ measured in a kinetic mode for 5 min. Clomipramine at its $\mathrm{IC}_{50}(6.5 \mu \mathrm{M})$ was used as positive and $0.1 \%(\mathrm{v} / \mathrm{v}) \mathrm{DMSO}$ as negative controls. Each compound was tested in triplicate. The results are expressed as percentage reduction of the TR activity. For $\mathrm{IC}_{50}$ determinations, inhibition assays were carried out at ten different concentrations and repeated four times.

In vitro assay with $\mathrm{T}$. cruzi blood stream forms - The assays with $T$. cruzi were carried out using blood from Swiss albino mice collected in the parasitaemia peak ( 7 th day) after infection with the Y strain of T. cruzi. The infected blood was diluted with normal murine blood and RPMI 1640 medium 1:2 (pH 7.2-7.4) to the concentration of $2 \times 10^{6}$ trypomastigotes $/ \mathrm{ml}$. Stock solutions at $10 \mathrm{mg} / \mathrm{ml}$ (25-59 $\mathrm{mM})$ of the compounds were prepared in dimethylsulfoxide (DMSO). A sample $(5.0 \mu \mathrm{l})$ of each solution was added to $195 \mu \mathrm{l}$ of infected blood providing a final concentration of $250 \mu \mathrm{g} / \mathrm{ml}(0.6-1.5 \mathrm{mM})$. Samples of $100 \mu \mathrm{l}$ were transferred in duplicate to the wells of a microtitre plate (96 wells). To reproduce the blood bank conditions, plates were incubated at $4^{\circ} \mathrm{C}$ for $24 \mathrm{~h}$. The experiments were repeated two times. Afterwards, the parasite concentration was evaluated using an optical microscope with a $400 \mathrm{X}$ magnification. DMSO at $2.5 \% \mathrm{v} / \mathrm{v}$ and gentian violet at its $\mathrm{IC}_{50}$ concentration $(7.5 \mu \mathrm{g} / \mathrm{ml})$ were used as negative and positive controls, respectively. DMSO was not added in the positive control. The parasite concentration reduction (parasite lysis) was determined in comparison with negative control containing only $2.5 \%$ DMSO. At $2.5 \%$ concentration DMSO in blood was found to cause no morphological alterations or lysis either in the parasites, erythrocytes or leukocytes. 
In vitro assay with $\mathrm{T}$. cruzi amastigote forms (Buckner et al. 1996 modified) - Parasites and culture procedures: $T$. cruzi (Tulahuen strain) expressing the Escherichia coli beta-galactosidase gene were grown on monolayer of mouse L929 fibroblasts. Cultures to be assayed for betagalactosidase activity were grown in RPMI 1640 medium (pH 7.2-7.4) without phenol red (Gibco BRL) plus 10\% fetal bovine serum, glutamine and gentamicin.

T. cruzi growth inhibition assay - Ninety-six-well tissue culture plates were seeded with L929 fibroblasts at $4.0 \times 10^{3}$ per well in $80 \mu 1$ and incubated overnight. Betagalactosidase-expressing trypomastigotes were then added at $4.0 \times 10^{4}$ per well in $20 \mu \mathrm{l}$. After $2 \mathrm{~h}$, the medium with trypomastigotes that not penetrated in cells was discarded and replaced by $200 \mu \mathrm{l}$ of fresh medium. After $48 \mathrm{~h}$, the medium was discarded again and replaced by $180 \mu 1$ of fresh medium and test compounds in $20 \mu \mathrm{l}$. Each compound was tested in triplicate. After 7 days of incubation, chlorophenol red beta-D-galactopyranoside (CPRG) (100 $\mathrm{mM}$ final concentration) and Nonidet P-40 ( $0.1 \%$ final concentration) were added to the plates and incubated overnight at $37^{\circ} \mathrm{C}$ and the absorbance measured at $570 \mathrm{~nm}$ in an automated micro plate reader. Benznidazole at its $\mathrm{IC}_{50}$ $(4.0 \mu \mathrm{M})$ was used as positive control. The results are expressed as percentage growth inhibition.

\section{RESULTS AND DISCUSSION}

The monoarylfurans 5-7, and the diarylfurans 9 were synthesized in a single step via the Meerwein arylation in moderate yields. Initial attempts to prepare 2,5-diarylfurans by this method were unsuccessful and only monoarylfurans were formed, except for compound $\mathbf{9}$, obtained with $12 \%$ yield. Under this reaction condition anilines containing electron donor substituents attached to the phenyl ring furnished only tarry material from which nei- ther mono nor diarylfurans could be isolated. Therefore, the 2,5-diarylfurans $\mathbf{8 , 1 0 - 1 5}$ were prepared in two steps using the Stille coupling. The structures of all compounds were confirmed by spectroscopy and physicochemical data (Table I).

Table II shows the results of the bioassays using the pure compounds 5-15 against TR and T. cruzi trypomastigote and amastigote forms. For the comparison of the activities standard control drugs were included in the assays.

The compounds were tested for inhibition of TR at 20 $\mu \mathrm{g} / \mathrm{ml}$ and the $\mathrm{IC}_{50}$ values were determined for the most active compounds. Thus, the nitro derivative $\mathbf{6}$ and the diacetamide 12 presented $\mathrm{IC}_{50}$ values of $155 \mu \mathrm{M}$ and 48.5 $\mu \mathrm{M}$, respectively. Many nitrofuran derivatives have been reported to act as subversive substrate for TR, a class of inhibitors that produce free radicals once reduced by the enzyme, thereby subverting its physiological role (JockersScherübl et al. 1989, Paulino et al. 2002, Maya et al. 2003, Chibale \& Musonda 2003, Aguirre el al. 2004). In the presence of oxygen, these inhibitors are cyclically reduced and reoxidized generating deleterious oxygen radicals while simultaneously inhibiting TR's ability to reduce its physiological substrate (Chibale \& Musonda 2003). Thus, the inhibitory activity presented by the nitro derivative $\mathbf{6}$ could be associated to its ability to act as subversive substrates. On the other hand the related diarylfuran 10, despite containing two $\mathrm{NO}_{2}$ groups, was less active than $\mathbf{6}$, probably due to its poor solubility in the assay medium. The diacetamide $\mathbf{1 2}$ was the best inhibitor and its activity may come from to the combination of the hydrophobic moiety with the amide groups. The amide groups may be important for the interaction between compound $\mathbf{1 2}$ and the enzyme via hydrogen bonds. However, further experimental evidences are needed to confirm such possibility.

TABLE I

Spectroscopic and physicochemical data for arylfurans

\begin{tabular}{|c|c|c|c|c|c|}
\hline Compd & Yield $(\%)$ & $\mathrm{mp}$ (obs.) $\left({ }^{\circ} \mathrm{C}\right)$ & $\mathrm{mp}($ lit. $)\left({ }^{\circ} \mathrm{C}\right)$ & $\operatorname{MS}(m / z)$ & ${ }^{1} \mathrm{H}$ NMR $200 \mathrm{MHz} \delta(\mathrm{ppm})$ \\
\hline 5 & 24 & $64.3-65.8$ & $61-63^{a}$ & $169,88,70,61$ & $\begin{array}{l}6.52(\mathrm{dd}, 1 \mathrm{H}) ; 7.81(\mathrm{dd}, 1 \mathrm{H}) ; 7.53 \\
(\mathrm{dd}, 1 \mathrm{H}) ; 7.63(\mathrm{~d}, 2 \mathrm{H}) ; 7.73(\mathrm{~d}, 2 \mathrm{H})\end{array}$ \\
\hline 6 & 48 & 133.9-134.4 & $134-135^{b}$ & $189,159,115,63$ & $\begin{array}{l}6.55(\mathrm{dd}, 1 \mathrm{H}) ; 6.87(\mathrm{~d}, 1 \mathrm{H}) ; 7.57(\mathrm{~d}, 1 \mathrm{H}) \\
7.78(\mathrm{~d}, 2 \mathrm{H}) ; 8.24(\mathrm{~d}, 2 \mathrm{H})\end{array}$ \\
\hline 7 & 30 & 243.4-244.2 & - & $223,03130^{c}$ & $\begin{array}{l}6.65(\mathrm{dd}, 1 \mathrm{H}) ; 7.13(\mathrm{~d}, 1 \mathrm{H}) ; 7.39(\mathrm{sl}, 2 \mathrm{H}) \\
7.82(\mathrm{~d}, 1 \mathrm{H}) ; 7.87(\mathrm{~m}, 4 \mathrm{H})\end{array}$ \\
\hline 8 & 40 & $86.1-87.3$ & $87^{d}$ & $220,105,77,61$ & $6.74(\mathrm{~s}, 2 \mathrm{H}) ; 7.23-7.78(\mathrm{~m}, 10 \mathrm{H})$ \\
\hline 9 & 12 & 291.4-293.1 & $294-295^{e}$ & $270,69,55,41$ & $6.96(\mathrm{~s}, 2 \mathrm{H}) ; 7.71(\mathrm{~d}, 4 \mathrm{H}) ; 7.83(\mathrm{~d}, 4 \mathrm{H})$ \\
\hline 10 & 72 & $269.8-271.2$ & $269-270^{f}$ & $310,280,234,189$ & $7.54(\mathrm{~s}, 2 \mathrm{H}) ; 8.13(\mathrm{~d}, 4 \mathrm{H}) ; 8.32(\mathrm{~d}, 4 \mathrm{H})$ \\
\hline 11 & 34 & $143.9-145.7$ & - & $356,337,183,145$ & $6.88(\mathrm{~s}, 2 \mathrm{H}) ; 7.67(\mathrm{~d}, 4 \mathrm{H}) ; 7.84(\mathrm{~d}, 4 \mathrm{H})$ \\
\hline 12 & 21 & $307-309$ & $307-308^{g}$ & $334,292,250,207$ & $\begin{array}{l}2.06(\mathrm{~s}, 6 \mathrm{H}) ; 6.92(\mathrm{~s}, 2 \mathrm{H}) ; 7.65(\mathrm{~d}, 4 \mathrm{H}) \\
7.72(\mathrm{~d}, 4 \mathrm{H}) ; 10.05(\mathrm{~s}, 2 \mathrm{H})\end{array}$ \\
\hline 13 & 35 & $189-190$ & $195-196^{h}$ & $280,265,135$ & $\begin{array}{l}3.86(\mathrm{~s}, 6 \mathrm{H}) ; 6.59(\mathrm{~s}, 2 \mathrm{H}) ; 6.95(\mathrm{~d}, 4 \mathrm{H}) \\
6.67(\mathrm{~d}, 4 \mathrm{H})\end{array}$ \\
\hline 14 & 26 & 158.6-158.9 & $154-155^{i}$ & $340,325,170,44$ & $\begin{array}{l}3.94(\mathrm{~s}, 6 \mathrm{H}) ; 4.00(\mathrm{~s}, 6 \mathrm{H}) ; 6.63(\mathrm{~s}, 2 \mathrm{H}) \\
6.93(\mathrm{~d}, 2 \mathrm{H}) ; 7.26(\mathrm{sl}, 2 \mathrm{H}) ; 7.33(\mathrm{~d}, 2 \mathrm{H})\end{array}$ \\
\hline $15^{j}$ & 40 & $140-140.9$ & - & $400,385,60$ & $\begin{array}{l}3.89(\mathrm{~s}, 6 \mathrm{H}) ; 3.95(\mathrm{~s}, 12 \mathrm{H}) ; 6.67(\mathrm{~s}, 2 \mathrm{H}) \\
6.95(\mathrm{~s}, 4 \mathrm{H})\end{array}$ \\
\hline
\end{tabular}

$a$ : Ohta et al. 1990; $b$ : Fisera et al 1974; $c$ : Calcd. for $\mathrm{C}_{10} \mathrm{H}_{9} \mathrm{NO}_{3} \mathrm{~S}(223,03031) ; d$ : Koga et al 1998; $e$ : Das \& Boykin 1977; $f$ Stephens et al 2001; $g$ : Jonh \& Robert 1958, $h$ : Bailey et al 1965; $i$ : Haworth \& Kelly 1937; $j$ : Anal. Calcd. for $\mathrm{C}_{22} \mathrm{H}_{24} \mathrm{O}_{7}$ : C 65.99 , $\mathrm{H} 6.04$. Found: C 65.64, H 5.57. 
TABLE II

Trypanothione reductase (TR) inhibition and trypanocidal activity of arylfurans

\begin{tabular}{|c|c|c|c|c|c|}
\hline \multirow[b]{2}{*}{ Compound } & \multicolumn{2}{|c|}{ TR inhibition } & \multicolumn{2}{|c|}{ Trypanocidal activity } & \multirow[b]{2}{*}{$\log \mathrm{P}^{a}$} \\
\hline & $\begin{array}{l}\text { Inhibition at } \\
20 \mu \mathrm{g} / \mathrm{ml}(\%)\end{array}$ & $\begin{array}{l}\mathrm{IC}_{50} \\
(\mu \mathrm{M})\end{array}$ & $\begin{array}{c}\text { Blood } \\
\text { trypomastigotes } \\
(\% \text { lysis at } 250 \mu \mathrm{g} / \mathrm{ml})\end{array}$ & $\begin{array}{l}\text { Intracellular } \\
\text { amastigotes } \\
(\% \text { growth inibition } \\
\text { at } 20 \mu \mathrm{g} / \mathrm{ml})\end{array}$ & \\
\hline Clomipramine & - & 6.5 & - & 72 & - \\
\hline Crystal violet & - & - & $53^{b}$ & - & - \\
\hline Benznidazole & - & - & - & $50^{c}$ & - \\
\hline 5 & 5 & - & 12 & 35 & 2.72 \\
\hline 6 & 34 & 155 & 16 & 30 & 2.63 \\
\hline 7 & 8 & - & 8 & 70 & 1.57 \\
\hline 8 & 4 & - & 21 & 25 & 4.13 \\
\hline 9 & 11 & - & 3 & 35 & 4.20 \\
\hline 10 & 9 & - & 2 & 25 & 4.04 \\
\hline 11 & 10 & - & 13 & 28 & 5.89 \\
\hline 12 & 54 & 48.5 & 5 & 15 & 0.39 \\
\hline 13 & 15 & - & 3 & 22 & 3.62 \\
\hline 14 & 7 & - & 6 & 65 & 3.24 \\
\hline 15 & 3 & - & 41 & 9 & 5.45 \\
\hline
\end{tabular}

The results in Table II show no correlation between enzyme inhibition and trypanocidal activity as the two major TR inhibitors, compounds 6 and 12, showed no effect against intact bloodstream or amastigote forms of the parasite. On the other hand, compound 15, inactive against TR, reduced by $41 \%$ the number of trypomastigotes in the blood while compounds $\mathbf{7}$ and $\mathbf{1 4}$ were able to inhibit by more than $60 \%$ the growth of intracellular amastigotes. Interestingly compound $\mathbf{1 4}$ is structurally related with the lignan veraguensin $\mathbf{3}$. Table II shows the calculated partition coefficients for the arylfurans 515. Partition coefficient between water and octanol (log $\mathrm{P}$ ) is regarded as a measure of lipophilicity of a drug and is related to its ability to cross biological membranes. Substances with high $\log \mathrm{P}$ values dissolve better in fats and oils than in water. This enhances their ability to enter lipid membranes by passive diffusion, thereby enhancing their potential for absorption. Generally, for a good activity the relationship appears to be parabolic with an optimum Log $P$ value of around $2 \pm 1$. It is well known that compounds with negative $\log \mathrm{P}$ values cross cell membranes very poorly (Lipinski et al. 1997). The log P values for compounds 11 and $\mathbf{1 5}$ are outside the optimum limits. Compound 6 has a reasonable $\log \mathrm{P}$ value but its $\mathrm{IC}_{50}$ is so high that an effective concentration inside the parasite would be difficult to reach. The low trypanocidal activity of the diamide $\mathbf{1 2}$ may be due to factors such as a) poor membrane permeability as indicated by its low $\log \mathrm{P}$ value $(\log \mathrm{P}=0.39)$; b) the in vitro assay with $T$. cruzi bloodstream forms mimics blood bank conditions and is carried in a short assay time $(24 \mathrm{~h})$ and low temperature $\left(4^{\circ} \mathrm{C}\right)$, making it difficult to detect the interference of the compound on the TR activity; c) In the intracellular assay with amastigotes the compound $\mathbf{1 2}$ could not be able to cross the fibroblast and parasite's cell membranes to reach parasite's cytoplasm in sufficient quantity to significantly inhibit TR. Therefore, a direct correlation between the trypanocidal activity and inhibition of TR by the compounds was not observed. Indeed, even clomipramine, one of the most potent inhibitor of TR presented only moderate activity (72\% inhibition) against intracellular amastigote forms at $57 \mu \mathrm{M}(20 \mu \mathrm{g} / \mathrm{ml})$.

Despite its failure to reduce parasites under the conditions used in the present work, compound $\mathbf{1 2}$ deserves further investigation to determine its TR inhibition mechanism and to develop related compounds with improved potency.

\section{ACKNOWLEDGMENTS}

To Prof. Alan Fairlamb, University of Dundee, Scotland, for providing the recombinant T. cruzi TR and to Prof. Frederick S Buckner, Univdersity of Washington, for providing the Tulahuen strain of $T$. cruzi expressing the E. coli beta-galactosidase gene used in this work.

\section{REFERENCES}

Aguirre G, Cabrera E, Cerecetto H, Maio RD, González M, Seoane G, Duffaut A, Denicola A, Gil MJ, Martinez-Merino V 2004. Design, synthesis and biological evaluation of new potent 5-nitrofuryl derivatives as anti-Trypanosoma cruzi agents. Studies of trypanothione binding site of trypanothione reductase as target for rational design. Eur $J$ Med Chem 39: 421-431.

Bailey PS, White HM, Colomb Jr HO 1965. Ozonation of diarylfurans. J Org Chem 30: 487-491.

Bond CS, Zhang Y, Berriman M, Cunningham ML, Fairlamb AH, Hunter WN 1999. Crystal structure of Trypanosoma cruzi trypanothione reductase in complex with trypanothione and the structure-based discovery of new natural product inhibitors. Structure 7: 81-89. 
Borges A, Cunningham ML, Tovar J, Fairlamb AH 1195. Sitedirected mutagenesis of the redox-active cysteines of Trypanosoma cruzi trypanothione reductase. Eur J Biochem 228: 745-752.

Buckner FS, Verlinde CLMJ, La Flamme AC, Van Voorkhis WC 1996. Efficient Technique for screening drugs for activity against Trypanosoma cruzi using parasites expressing $\beta$ Galactosidase. Antimicrob Agent Chemother 40: 2592-2597.

Chibale K, Musonda CC 2003. The synthesis of parasitic cysteine protease and trypanothione reductase inhibitors. Curr Med Chem 10: 1863-1889.

Das BP, Boykin DW 1977. Synthesis and antiprotozoal activity of 2,5-bis(4-guanylphenyl)furans. J Med Chem 20: 531536.

Fisera L, Kovác J, Komanová E 1974. A convenient new method of arylation of furan reaction of diazoaminobenzenes with furan and isopenthyl nitrite. Tetrahedron 30: 4123-4127.

Hamilton CJ, Saravanamuthu A, Eggleston IM, Fairlamb AH 2003. Ellman's-reagent-mediated regeneration of trypanothione in situ: substrate-economical microplate and time-dependent inhibition assays for trypanothione reductase. Biochem J 369: 529-537.

Haworth RD, Kelly WM 1937. Constitution of natural phenolic resins. IX. Structure of lariciresinol and preliminary experiments on the synthesis of lignandiols. J Chem Soc: 1645-1649.

Jensen S, Hansen J, Boll PM 1993. Lignans and neolignans from piperaceae. Phytochemistry 33: 523-530.

Jockers-Scherübl MC, Schirmer RH, Krauth-Siegel RL 1989. Trypanothione reductase from Trypanosoma cruzi. Catalytic properties of the enzyme and inhibition studies with trypanocidal compounds. Eur J Biochem 180: 267-272.

John EP, Robert SL 1958. 2,5-bis-( $p$-aminophenyl)furan azo derivatives. US2852503.

Koga Y, Kusama H, Narasaka K 1998. Preparations of furans from a-bromo ketones and enol ethers catalyzed by a rhenium(I) nitrogen complex. Bull Chem Soc Jpn 7: 475482.

Kuwano M, Ono M, Tomita M, Watanabe J, Takeda M 1994. Vascularization inhibitor and novel compound. W09415594.

Lanteri CA, Trumpower BL, Tidwell RR, Meshnick SR 2004. DB75, a novel trypanocidal agent, disrupts mitochondrial function in Saccharomyces cerevisiae. Antimicrob Agents Chemother 48: 3968-3974.

Lipinsk CA, Lombardo F, Dominy BW, Feeney PJ 1997. Experimental and computational approaches to estimate solubility and permeability in drug discovery and development settings. Adv Drug Delivery Rev 23: 3-25.

Lockhart DJ, Patel HK, Mehta SA, Milanov ZV, Grotzfeld RM, Lai AG 2004. Heterocyclic compounds and uses thereof. WO2004110357.
Lopes NP, Chicaro R, Kato MJ, Albuquerque S, Yoshida M 1998. Flavonoids and lignans from Virola surinamensis twigs and their in vitro activity against Trypanosoma cruzi. Planta Med 64: 667-669.

Maya JD, Bollo S, Núñez-Vergara LJ, Squella JA, Repetto Y, Morello A, Périé J, Chauvière G 2003. Trypanosoma cruzi: effect and mode of actino of nitroimidazole and nitrofuran derivatives. Biochem Pharmacol 65: 999-1006.

Moraes-Souza H, Bordin JO, Bardossy L, Macpherson DW, Blajchman MA 1995. Preventon of transfusion-associated Chagas' disease: efficacy of white cell-reduction filters in removing Trypanosoma cruzi from infected blood. Transfusion 35: 723-726.

Mitsch A, Wißner P, Silber K, Haebel P, Sattler I, Klebe G, Schlitzer M 2004. Non-thiol farnesyltransferase inhibitors: $N$ - (4 - tolylacetyla mino-3-benzoylpheny 1$)-3$ arylfurylacrylic acid amides. Bioorg Med Chem 12: 45854600.

Ohta A, Akita Y, Ohkuwa T, Chiba M, Fukunaga R, Miyafuji A, Nakata T, Tani N, Aoyagi Y 1990. Palladium-catalyzed arylation of furan, thiophene, benzo[b]furan and benzo[b]thiophene. Heterocycles 31: 1951-1958.

Paulino M, Iribarne F, Hansz M, Vega M, Seoane G, Cerecetto H, Di Maio R, Caracelli I, Zukerman-Schpector J, Olea C, Stoppani AOM, Berriman M, Fairlamb AH, Tapia O 2002. Computer assisted design of potentially active antitrypanosomal compounds. J Mol Struct (Theochem) 584: 95-105.

Perrier H, Bayly C, Laliberté F, Huang Z, Rasori R, Robichaud A, Girard Y, Macdonald D 1999. Substituted furans as inhibitors of the PDE4 enzyme. Bioorg Med Chem Lett 9: 323-326.

Rondestvedt CS 1976. Arylation of unsaturated compounds by diazonium salts (The Meerwein arylation reaction). Org React 24: 225-259.

Schmidt A, Krauth-Siegel RL 2002. Enzymes of the trypanothione metabolism as targets for antitrypanosomal drug development. Curr Top Med Chem 2: 1239-1259.

Schmunis GA 1991. Trypanosoma cruzi, the etiologic agent of Chagas' disease: status in blood supply in endemic and no endemic countries. Transfusion 31: 547-557.

Seitz DE, Lee SH, Hanson RN, Bottaro JC 1983. Synthesis and reactivity of the 2,5-bis(trimethylstannyl) derivatives of thiophene and furan. Synthetic Commun 13: 121-128.

Stephens CE, Tanious F, Kim S, Wilson WD, Schell WA, Perfect JR, Franzblau SG, Boykin DW 2001. Diguanidino and "reversed" diamidino 2,5-diarylfurans as antimicrobial agents. J Med Chem 44: 1741-1748.

Wendel S 1993. Blood banking preventive approaches for Chagas disease. Mem Inst Oswaldo Cruz 88 (Suppl.): 59-60.

WHO-World Health Organization 2002. TDR diseases. WHO Health reports, http://www.who.int/tdr/diseases 